(c) American Dairy Science Association, 2005.

\title{
Digestible Reactive Lysine in Selected Milk-Based Products
}

\author{
S. M. Rutherfurd ${ }^{1}$ and P. J. Moughan ${ }^{2}$ \\ ${ }^{1}$ Institute of Food, Nutrition and Human Health and \\ ${ }^{2}$ Riddet Centre, Massey University, Palmerston North, New Zealand
}

\section{ABSTRACT}

Reactive lysine contents, true ileal reactive lysine digestibility, and true ileal digestible reactive lysine contents were determined in a wide range of processed milk products. A previously validated assay based on determining reactive lysine in both food and ileal digesta, after reaction of these materials with O-methylisourea, was applied. Semisynthetic diets containing milk products as the sole sources of protein and including chromic oxide as an indigestible marker were fed to growing rats. Digesta from the terminal ileum were collected posteuthanasia and, with samples of the diets, analyzed for reactive lysine (homoarginine) contents. True reactive lysine digestibility was determined after correcting for endogenous lysine loss at the terminal ileum of rats fed an enzyme hydrolyzed casein-based diet, followed by ultrafiltration $(5000 \mathrm{Da})$ of the digesta. Digestible total lysine (determined using conventional methods) was also determined. The true ileal reactive lysine digestibility was high $(>91 \%)$ in all the milk products tested, but was highest in the UHT milk (100\%) and lowest in the infant formulas (91 to 93\%). Total lysine digestibility (conventional measurement) significantly underestimated reactive lysine digestibility for all the products tested. The mean underestimation ranged from 1.3 to $7.1 \%$ units. The mean digestible total lysine content was significantly different from the available lysine content for most of the products examined. In some cases this difference was small $(<3 \%)$, but for a number of the products (evaporated milk, whole milk protein, lactose hydrolyzed milk powder, and a sports formula) the difference was greater (6.5 to 14\%). This would suggest firstly that total lysine and total lysine digestibility determined using conventional methods were inaccurate when applied to some milkbased foods, and secondly that some of the milk products have undergone lysine modification. In general, milk proteins are a highly digestible source of amino acids and lysine.

Received March 14, 2004.

Accepted August 23, 2004.

Corresponding author: S. M. Rutherfurd; e-mail: S.M.Rutherfurd @massey.ac.nz.
(Key words: lysine, milk, availability, digestibility)

Abbreviation key: EHC = enzymatically hydrolyzed casein.

\section{INTRODUCTION}

Lysine is a dietary essential AA that is sometimes first limiting in diets for humans, particularly diets high in cereals. Generally, milk proteins contain relatively high amounts of lysine, especially in comparison with cereal protein sources; therefore, milk protein products are a valued source of lysine. Lysine, however, is susceptible to modification during processing or prolonged storage, whereupon the side chain amino group of lysine can react with lactose or other compounds to produce nutritionally unavailable (unreactive) derivatives (Hurrell and Carpenter, 1981; Moughan, 2003). Some of these derivatives are acid labile and will revert back to lysine under the acid hydrolysis conditions used to determine lysine contents in food samples. This reversion is not quantitative and leads to inaccurate estimates of amino acid digestibility, and generally to an overestimation of the available (reactive) lysine content and the digestible lysine contents of processed foods. Numerous methods have been developed to determine chemically reactive lysine, often incorrectly referred to as available lysine, in milk products (Ferrer et al., 2003; Pereyra Gonzales et al., 2003; Ramirez-Jimenez et al., 2004), but few researchers have determined biologically available lysine in any protein sources (Batterham et al., 1990), including milk products. A method has been developed (Moughan and Rutherfurd, 1996; Rutherfurd et al., 1997) that allows accurate measurement of the available lysine content of processed foods. The assay (true ileal reactive lysine digestibility) involves feeding a test diet to an animal. Ileal digesta are collected and reactive lysine is measured in both diet and digesta. The difference between the 2 measurements reflects the reactive lysine that has been digested and absorbed. Ileal rather than fecal measurements are used, firstly, as fecal measurements are confounded by microorganisms in the hindgut that metabolize AA, and secondly, it does not appear that AA are absorbed from the hindgut in quantitatively significant amounts (Moughan, 2003). The aim of this study was to determine reactive 
Table 1. Crude protein, total fat, and total carbohydrate contents ${ }^{1}$ ( $\mathrm{g} / 100 \mathrm{~g}$ of air dry weight) for the 12 protein sources.

\begin{tabular}{|c|c|c|c|}
\hline & $\mathrm{CP}$ & $\begin{array}{l}\text { Total } \\
\text { fat }\end{array}$ & $\begin{array}{l}\text { Total } \\
\text { carbohydrate }\end{array}$ \\
\hline Whey protein concentrate & 78.5 & 4.9 & 8.6 \\
\hline UHT milk ${ }^{2}$ & 3.5 & 0.5 & 4.8 \\
\hline Evaporated milk ${ }^{2}$ & 8.4 & 8.6 & 11.6 \\
\hline Lactose-hydrolyzed milk powder ${ }^{3}$ & 34 & 12 & 44.2 \\
\hline High-protein supplement & 19.9 & 5.7 & 30.3 \\
\hline Sports formula ${ }^{4}$ & 24.5 & 0.6 & 66.1 \\
\hline Weight gain formula ${ }^{5}$ & 28.0 & 1.8 & 62.0 \\
\hline Infant formula $\mathrm{A}$ & 11.4 & 29.3 & 57 \\
\hline Infant formula $B$ & 12 & 28 & 51 \\
\hline Infant formula $\mathrm{C}$ & 15.4 & 21 & 56 \\
\hline Whole milk powder & 32.2 & 28.8 & 36.2 \\
\hline Elderly formula ${ }^{6}$ & 14.0 & 15.9 & 60.7 \\
\hline
\end{tabular}

${ }^{1}$ Data taken from the statutory label information appearing on the product.

${ }^{2}$ These products are liquids, and, as such, the protein and carbohydrate contents are $\mathrm{g} / 100 \mathrm{~mL}$.

${ }^{3}$ Hydrolyzed milk-based food for lactose intolerance.

${ }^{4}$ Milk-based formula designed for athletes and sports people.

${ }^{5}$ Milk-based formula designed for bodybuilders and people needing to gain BW.

${ }^{6}$ Milk-based formula for the elderly.

lysine content, true ileal reactive lysine digestibility, and true ileal digestible reactive lysine content in a range of high-quality milk protein sources using the new assay and to compare these values with total lysine content, true ileal total lysine digestibility, and true ileal digestible total lysine content determined using the traditional approach. Information on the available lysine content of a range of milk-based products was obtained.

\section{MATERIALS AND METHODS}

\section{Materials}

O-methylisourea was obtained from Sigma Chemicals (St. Louis, MO), and barium hydroxide octahydrate was obtained from BDH Laboratory Supplies (Poole, England). A total of 12 milk-based protein products were obtained locally. These included a whole milk powder, 3 infant formulas, whey protein concentrate, UHT milk, evaporated milk, weight gain formula, milk powder-based sports drink, milk powder-based formula for the elderly, lactose-hydrolyzed milk powder, and a milk powder-based high-protein supplement. The crude protein, total fat, and total carbohydrate contents of the 12 products (as given in the product specifications) are shown in Table 1. Enzymatically hydrolyzed casein was obtained from New Zealand Pharmaceuticals Ltd. (Palmerston North, New Zealand) and contained free AA and peptides $\leq 2000$ Da. Centriprep YM-3 disposable ultrafiltration devices (with a 3000-Da MW cutoff) were obtained from Amicon, Inc. (Beverly, MA). Laboratory rats were obtained from the Small Animal Production Unit, Massey University (Palmerston North, New Zealand).

\section{Preparation of Protein Sources}

Most products were purchased as finely ground powders. Any products purchased as liquids were freezedried and then ground through a 1-mm mesh.

\section{Digestibility Study}

A total of 60 male Sprague-Dawley rats, approximately $150 \mathrm{~g} \mathrm{BW}$, were housed individually in stainless steel wire-bottomed cages in a room maintained at $22 \pm$ $2^{\circ} \mathrm{C}$, with a 12 -h light-dark cycle. Twelve semisynthetic test diets were formulated (Table 2 ) to each contain 100 $\mathrm{g} / \mathrm{kg}$ of CP. An enzymatically hydrolyzed casein (EHC)based diet was also formulated (Table 2) to allow determination of endogenous ileal lysine flows (Moughan et al., 1990; Butts et al., 1991). Chromic oxide was included $(0.3 \%)$ in each diet as an indigestible marker. All diets met the nutritional requirements for the growing rat with the exception of protein (National Research Council, 1995). The animals were randomly allocated to the dietary treatments and were fed the diets for a 14-d experimental period. On each day, each rat received its respective diet as 9 meals given hourly (0830 to $1630 \mathrm{~h}$ ); each mealtime consisted of a 10 -min period during which the rats had unrestricted access to their diet. Water was available at all times. On the final day of the study, from 5.5 to $7 \mathrm{~h}$ after the start of feeding, the rats were asphyxiated in carbon dioxide gas and then decapitated. The $20 \mathrm{~cm}$ of ileum immediately anterior to the ileo-cecal junction was dissected out. The dissected ileum was washed with distilled, deionized water to remove any blood and hair, and carefully dried on absorbent paper. The digesta were gently flushed from the ileum section and freeze-dried ready for chemical analysis. The digesta of rats fed the EHC diet were adjusted to approximately $\mathrm{pH} 3$ with $6 \mathrm{M} \mathrm{HCl}$ to minimize protease activity. The EHC digesta were centrifuged and ultrafiltered (3000 Da) and then freeze-dried in preparation for analysis (Butts et al., 1991).

Ethics approval for the animal trial was obtained from the Animal Ethics Committee, Massey University.

\section{Chemical Analysis}

Amino acid contents were determined in duplicate 5mg protein source and digesta samples and quadruplicate 5-mg semisynthetic diet samples using a Waters ion-exchange HPLC system, utilizing postcolumn nin- 
Table 2. Ingredient compositions ${ }^{1}$ ( $\mathrm{g} / \mathrm{kg}$ of air dry weight) of the experimental diets.

\begin{tabular}{|c|c|c|c|c|c|c|c|c|c|c|c|c|c|}
\hline & $\mathrm{EHC}^{2}$ & $\mathrm{WPC}^{3}$ & $\begin{array}{l}\text { UHT } \\
\text { milk }\end{array}$ & $\begin{array}{l}\text { Evaporated } \\
\text { milk }\end{array}$ & $\begin{array}{l}\text { Lactose- } \\
\text { hydrolyzed } \\
\text { milk } \\
\text { powder }\end{array}$ & $\begin{array}{l}\text { High } \\
\text { protein } \\
\text { supplement }\end{array}$ & $\begin{array}{l}\text { Sports } \\
\text { formula }\end{array}$ & $\begin{array}{l}\text { Weight } \\
\text { gain } \\
\text { formula }\end{array}$ & $\begin{array}{l}\text { Infant } \\
\text { formula A }\end{array}$ & $\begin{array}{l}\text { Infant } \\
\text { formula B }\end{array}$ & $\begin{array}{l}\text { Infant } \\
\text { formala } \mathrm{C}\end{array}$ & $\mathrm{WMP}^{4}$ & $\begin{array}{l}\text { Elderly } \\
\text { formula }\end{array}$ \\
\hline Wheat starch & 637.0 & 639.6 & 493.9 & 462.7 & 472.9 & 264.5 & 358.8 & 409.9 & 89.8 & 133.7 & 317.6 & 466.0 & 52.7 \\
\hline Soybean oil & 50.0 & 50.0 & 50.0 & 50.0 & 50.0 & 50.0 & 50.0 & 50.0 & $\ldots$ & $\ldots$ & $\ldots$ & 50.0 & 50.0 \\
\hline Cellulose & 50.0 & 50.0 & 50.0 & 50.0 & 50.0 & 50.0 & 50.0 & 50.0 & $\ldots$ & $\ldots$ & $\ldots$ & 50.0 & 50.0 \\
\hline Sucrose & 100.0 & 100.0 & 100.0 & 100.0 & 100.0 & 100.0 & 100.0 & 100.0 & $\ldots$ & $\ldots$ & $\ldots$ & 100.0 & 100.0 \\
\hline Vitamin premix ${ }^{5}$ & 0.5 & 0.5 & 0.5 & 0.5 & 0.5 & 0.5 & 0.5 & 0.5 & 0.5 & 0.5 & 0.5 & 0.5 & 0.5 \\
\hline Mineral premix ${ }^{5}$ & 3.5 & 3.5 & 3.5 & 3.5 & 3.5 & 3.5 & 3.5 & 3.5 & 3.5 & 3.5 & 3.5 & 3.5 & 3.5 \\
\hline Dicalcium phosphate & 24.0 & 24.0 & 24.0 & 24.0 & 24.0 & 24.0 & 24.0 & 24.0 & 24.0 & 24.0 & 24.0 & 24.0 & 24.0 \\
\hline EHC & 130.0 & & $\ldots$ & $\ldots$ & $\ldots$ & $\ldots$ & $\ldots$ & $\ldots$ & $\ldots$ & $\ldots$ & $\ldots$ & $\ldots$ & $\ldots$ \\
\hline WPC & $\ldots$ & 127.4 & $\ldots$ & $\ldots$ & $\ldots$ & $\ldots$ & $\ldots$ & $\ldots$ & $\ldots$ & $\ldots$ & $\ldots$ & $\ldots$ & $\ldots$ \\
\hline UHT milk & $\ldots$ & $\ldots$ & 273.1 & & $\ldots$ & $\ldots$ & $\ldots$ & $\ldots$ & $\ldots$ & $\ldots$ & $\ldots$ & $\ldots$ & $\ldots$ \\
\hline Evaporated milk & $\ldots$ & $\ldots$ & $\ldots$ & 304.3 & $\ldots$ & $\ldots$ & $\ldots$ & $\ldots$ & $\ldots$ & $\ldots$ & $\ldots$ & $\ldots$ & $\ldots$ \\
\hline $\begin{array}{l}\text { Lactose-hydrolyzed milk } \\
\text { powder }\end{array}$ & $\ldots$ & $\ldots$ & $\ldots$ & $\ldots$ & 294.1 & $\ldots$ & $\ldots$ & $\ldots$ & $\cdots$ & $\cdots$ & $\cdots$ & $\ldots$ & $\cdots$ \\
\hline High-protein supplement & $\ldots$ & $\ldots$ & $\ldots$ & $\ldots$ & $\ldots$ & 502.5 & & $\ldots$ & $\ldots$ & $\ldots$ & $\ldots$ & $\ldots$ & $\ldots$ \\
\hline Sports formula & $\ldots$ & $\ldots$ & $\ldots$ & $\ldots$ & $\ldots$ & $\ldots$ & 408.2 & & $\ldots$ & $\ldots$ & $\ldots$ & $\ldots$ & $\ldots$ \\
\hline Weight gain formula & $\ldots$ & $\ldots$ & $\ldots$ & $\ldots$ & $\ldots$ & $\ldots$ & $\ldots$ & 357.1 & $\ldots$ & $\ldots$ & $\ldots$ & $\ldots$ & $\ldots$ \\
\hline Infant formula $A$ & $\ldots$ & $\ldots$ & $\ldots$ & $\ldots$ & $\ldots$ & $\ldots$ & $\ldots$ & $\ldots$ & 877.2 & & $\ldots$ & $\ldots$ & $\ldots$ \\
\hline Infant formula $\mathrm{B}$ & $\cdots$ & $\cdots$ & $\ldots$ & $\cdots$ & $\cdots$ & $\cdots$ & $\cdots$ & $\ldots$ & $\ldots$ & 833.3 & & $\ldots$ & $\cdots$ \\
\hline Infant formula $\mathrm{C}$ & $\ldots$ & $\ldots$ & $\ldots$ & $\ldots$ & $\ldots$ & $\ldots$ & $\ldots$ & $\ldots$ & $\ldots$ & $\ldots$ & 649.4 & & $\ldots$ \\
\hline WMP & $\ldots$ & $\ldots$ & $\ldots$ & $\ldots$ & $\ldots$ & $\ldots$ & $\ldots$ & $\ldots$ & $\ldots$ & $\ldots$ & $\ldots$ & 301.0 & $\ldots$ \\
\hline Elderly formula & $\ldots$ & $\ldots$ & $\ldots$ & $\ldots$ & $\ldots$ & $\ldots$ & $\ldots$ & $\ldots$ & & & & & 714.3 \\
\hline Chromic oxide & 5.0 & 5.0 & 5.0 & 5.0 & 5.0 & 5.0 & 5.0 & 5.0 & 5.0 & 5.0 & 5.0 & 5.0 & 5.0 \\
\hline
\end{tabular}

${ }^{1}$ All diets were formulated to contain equal CP contents.

${ }^{2} \mathrm{EHC}=$ Enzymatically hydrolyzed casein diet, used for determining endogenous amino acid losses at the terminal ileum. The EHC contained free AA and small peptides $(<2000 \mathrm{Da})$.

${ }^{3} \mathrm{WPC}=$ Whey protein concentrate.

${ }^{4} \mathrm{WMP}=$ Whole milk powder.

${ }^{5}$ Vitamin/mineral mix was formulated to meet the requirement of the growing rat for vitamins and minerals in the final diets (National Research Council, 1995). 
Table 3. Total and reactive lysine contents (mg/g of air dry weight) for 12 dairy protein sources.

\begin{tabular}{lccc}
\hline & Total $^{1}$ & Reactive $^{1}$ & ${\text { Overestimation }(\%)^{2}}^{2}$ \\
\hline Whole milk powder & 27.5 & 24.4 & 12.8 \\
Infant formula A & 9.6 & 9.5 & 0.9 \\
Infant formula B & 10.2 & 10.0 & 2.2 \\
Infant formula C & 12.5 & 12.5 & -0.5 \\
Whey protein concentrate & 83.0 & 78.6 & 5.6 \\
UHT milk & 32.0 & 31.4 & 1.8 \\
Evaporated milk & 26.1 & 21.2 & 23.0 \\
Weight gain formula & 25.2 & 24.3 & 3.8 \\
Sports formula & 21.4 & 19.5 & 9.7 \\
Elderly formula & 12.4 & 12.2 & 1.7 \\
Lactose-hydrolyzed milk powder & 28.3 & 25.5 & 11.1 \\
High-protein supplement & 14.6 & 14.4 & 1.9 \\
\hline
\end{tabular}

${ }^{1}$ Mean values based on duplicates.

${ }^{2}$ Overestimation $(\%)=\frac{\text { total lysine }- \text { reactive lysine }}{\text { total lysine }} \times \frac{100}{1}$.

hydrin derivatization and detection using absorbance at 570 and $440 \mathrm{~nm}$, following hydrolysis in $6 \mathrm{M}$ glassdistilled $\mathrm{HCl}$ containing $0.1 \%$ phenol for $24 \mathrm{~h}$ at $110 \pm$ $2{ }^{\circ} \mathrm{C}$ in evacuated sealed tubes. Cysteine, methionine, and tryptophan were not determined, as they are destroyed during acid hydrolysis. The weight of each AA was calculated using free amino acid molecular weights.

Reactive lysine contents were determined in duplicate 5-mg protein source and digesta samples and quadruplicate 5-mg diet samples after incubation for 1,7 , and $7 \mathrm{~d}$, respectively, in $0.6 \mathrm{M}$ O-methylisourea, $\mathrm{pH}$ $10.6\left(\mathrm{pH} 11.0\right.$ for the digesta samples), at $21^{\circ} \mathrm{C}$ in a shaking waterbath, with the reagent to lysine ratio being $>1000$, according to the procedure of Moughan and Rutherfurd (1996). The 0.6 M O-methylisourea solution was prepared as described by Moughan and Rutherfurd (1996). After incubation, the samples were dried using a Speedvac concentrator (Savant Instruments, Inc., Farmingdale, NY) and analyzed for AA content as described previously.

The chromium contents of the diet and ileal digesta samples were determined in duplicate on a GBC $902 \mathrm{AA}$ absorption/emission spectrophotometer (GBC Scientific NZ Ltd, Auckland, New Zealand) following the method of Costigan and Ellis (1987).

\section{Data Analysis}

Ileal total and ileal endogenous (EHC diet) AA flows at the terminal ileum were calculated using the following equation (units are $\mu \mathrm{g} / \mathrm{g}$ of DMI):

$$
\text { ileal AA flow }=\text { ileal } \mathrm{AA} \times \frac{\text { diet chromium }}{\text { ileal chromium }} .
$$

True ileal AA digestibility was calculated using the following equation (units are $\mu \mathrm{g} / \mathrm{g}$ of DMI):

$$
\begin{gathered}
\text { true AA digestibility }(\%)= \\
\text { dietary AA - } \\
\frac{(\text { ileal AA flow - endogenous AA flow }) \times 100}{\text { dietary AA }} .
\end{gathered}
$$

True ileal reactive lysine digestibility was calculated using the following equation (units are $\mu \mathrm{g} / \mathrm{g}$ of DMI):

true reactive lysine digestibility $(\%)=$

dietary reactive lysine* ${ }^{*}$ (ileal reactive

$\underline{\text { lysine flow }- \text { endogenous reactive lysine flow) } \times 100}$.

$$
\text { dietary reactive lysine }
$$

The AA digestibility data were subjected to a one-way ANOVA for each amino acid singly (GLM procedure; SAS, 1999).

\section{RESULTS}

\section{Comparison of Total and Reactive Lysine Contents for the Protein Sources}

Total and reactive lysine contents were determined for the 12 milk protein products (Table 3). For the infant formulas, UHT milk, elderly formula, and high-protein supplement, the difference between total and reactive lysine contents was $\leq 2.2 \%$. For the other products, total lysine overestimated reactive lysine from $3.8 \%$ for the weight gain formula to as much as $23 \%$ for evaporated milk.

*Reactive lysine was determined using the guanidination method. 
Table 4. Mean $(\mathrm{n}=5)$ true ileal total lysine digestibility $(\%)$ determined using conventional AA analysis and true ileal reactive-lysine digestibility $(\%)$ based on reactive lysine determined using guanidination prior to AA analysis.

\begin{tabular}{llcll}
\hline & \multicolumn{2}{c}{ Lysine digestibility } & & \\
\cline { 2 - 3 } & Total $^{1}$ & Reactive $^{2}$ & & Overall \\
SE $^{3}$ & Significance \\
\hline Whole milk powder & 95.2 & 98.3 & 0.87 & $* * *$ \\
Infant formula A & 86.9 & 91.0 & 1.71 & $* * *$ \\
Infant formula B & 88.6 & 92.3 & 1.03 & $* * *$ \\
Infant formula C & 89.0 & 93.1 & 1.20 & $* *$ \\
Whey protein concentrate & 96.3 & 98.5 & 0.71 & $* * *$ \\
UHT milk & 99.2 & 100.2 & 0.31 & $* *$ \\
Evaporated milk & 89.6 & 96.7 & 2.02 & $* *$ \\
Weight gain formula & 96.7 & 99.0 & 0.61 & $* * *$ \\
Sports formula & 95.2 & 98.0 & 0.56 & $* *$ \\
Elderly formula & 94.3 & 97.1 & 0.54 & $* *$ \\
Lactose-hydrolyzed milk powder & 96.2 & 98.6 & 0.62 & $* * *$ \\
High-protein supplement & 97.4 & 99.9 & 1.11 & $* *$ \\
\hline
\end{tabular}

\footnotetext{
${ }^{1}$ Lysine digestibility was determined using a true ileal amino acid digestibility assay (rat), and conventional amino acid analysis was used to quantitate total lysine in the diets and digesta.

${ }^{2}$ Lysine digestibility was determined using a true ileal amino acid digestibility assay (rat) and the guanidination reaction was used to quantitate reactive lysine in the diets and digesta.

${ }^{3}$ Overall SE is the standard error for total and reactive lysine digestibility combined.

$* P<0.05$.

$* * P<0.01$

$* * * P<0.001$.
}

\section{Comparison of True Ileal Lysine Digestibility Based on Either Reactive Lysine or Total Lysine}

True ileal lysine digestibility based on "total" lysine was determined for the 12 milk-based protein sources using conventional amino acid analysis and compared with true ileal reactive lysine digestibility, determined after guanidination of the underivatized lysine in the diet and digesta, to form homoarginine and subsequent analysis of homoarginine by HPLC (Table 4). The reactive lysine digestibility (lysine availability) was in excess of $90 \%$ for all of the protein products tested, indicating that most of the reactive lysine was absorbed.

For all of the products tested, true ileal reactive lysine digestibility (lysine availability), determined using the new assay, was statistically significantly higher than true ileal total lysine digestibility, determined using the conventional assay. On average, total lysine digestibility underestimated lysine availability by $3.3 \%$, and this underestimation ranged from $1.2 \%$ for UHT milk to $7.4 \%$ for evaporated milk.

Digestible total lysine (conventional analysis) and digestible reactive lysine (available lysine) contents are shown in Table 5. True ileal digestible total lysine was statistically significantly different from true ileal digestible reactive lysine (available lysine) for all of the milk protein products tested with the exception of the high-protein supplement. For the whole milk protein, whey protein concentrate, UHT milk, evaporated milk, weight gain formula, sports formula, and lactose-hy- drolyzed milk powder, conventional analysis (digestible total lysine) overestimated digestible reactive lysine; for the infant formulas and elderly formula, conventional analysis underestimated digestible reactive lysine. For infant formula B, UHT milk, weight gain formula, and elderly formula, the difference between digestible total lysine and digestible reactive lysine was $<3 \%$. For the other milk protein products, where statistically significant differences were observed, these differences ranged from 3.2 to $13.9 \%$ but were on average approximately $4.7 \%$.

\section{Comparison of the lleal Digestibility of Acid-Stable Amino Acids in Protein Sources With and Without the Guanidination Treatment}

True ileal amino acid digestibility values for the acidstable amino acids except lysine, proline, and arginine were also determined and are shown in Table 6. Overall, amino acid digestibility was high, with a mean true digestibility for all amino acids over all protein products of $91 \%$. Generally, digestibility was lowest for glycine $(69 \%)$ and highest for tyrosine (98\%). The mean digestibility for all AA was lowest for the infant formula A (81\%) and highest for UHT milk (97\%).

A paired $t$-test was used to compare the mean true ileal digestibilities (for each AA individually) for the acid-stable AA determined using the new and conventional methods for the 12 protein products. For most (61\%) of the AA, there was no significant difference 
Table 5. Mean ${ }^{1}$ digestible total and reactive lysine contents ( $\mathrm{g} / \mathrm{kg}$ of air dry weight) for 12 dairy protein sources

\begin{tabular}{lllll}
\hline & \multicolumn{2}{c}{ Digestible lysine } & & \\
\cline { 2 - 3 } & Total $^{1}$ & Reactive $^{2}$ & & Overall \\
SE & Significance \\
\hline Whole milk protein & 26.2 & 24.0 & 0.42 & $* * * *$ \\
Infant formula A & 8.3 & 8.6 & 0.12 & $* *$ \\
Infant formula B & 9.1 & 9.2 & 0.08 & $* *$ \\
Infant formula C & 11.1 & 11.7 & 0.14 & $* *$ \\
Whey protein concentrate & 79.9 & 77.5 & 0.58 & $* * *$ \\
UHT milk & 31.7 & 31.4 & 0.06 & $*$ \\
Evaporated milk & 23.4 & 20.5 & 0.60 & $* * *$ \\
Weight gain formula & 24.4 & 24.1 & 0.12 & $* *$ \\
Sports formula & 20.4 & 19.1 & 0.22 & $* * *$ \\
Elderly formula & 11.7 & 11.8 & 0.05 & $*$ \\
Lactose-hydrolyzed milk powder & 27.2 & 25.1 & 0.38 & $* * *$ \\
High-protein supplement & 14.3 & 14.3 & 0.11 & $\mathrm{NS}^{4}$ \\
\hline
\end{tabular}

\footnotetext{
${ }^{1}$ Digestible total lysine was calculated from true ileal lysine digestibility (rat), with lysine determined by conventional AA analysis and from the total lysine content in the protein source, also determined using conventional AA analysis.

${ }^{2}$ Digestible reactive lysine was calculated from true ileal reactive lysine digestibility (rat, guanidination analysis) and the reactive lysine content of the protein source, also determined using guanidination.

${ }^{3}$ Overall SE is the standard error for total and reactive lysine digestibility combined.

${ }^{4} P>0.05$.

$* P<0.05$.

$* * P<0.01$.

$* * * P<0.001$.
}

between digestibility determined either with or without guanidination prior to AA analysis. For a further $19 \%$ of the AA, there was a statistically significant difference between methods, but the actual difference between the mean digestibility for the 2 methods was $<3 \%$, which in practical terms may not be meaningful. For the remaining $20 \%$ of the AA determined, there was a statistically significant difference between the 2 methods and the difference was $>3 \%$.

\section{DISCUSSION}

It is important to have accurate information on the amount of lysine present in foods and the digestibility and availability of the lysine, as lysine is an important dietary essential AA that is often found in relatively low amounts in cereal-based diets. Lysine possesses a reactive amino group on its side chain, which is capable of reacting with other compounds present in a food to form nutritionally unavailable derivatives (e.g., Maillard products) when a food is processed or stored (Hurrell and Carpenter, 1981). Some of these products, although structurally different from lysine, can revert back to lysine when the food is subjected to the acid hydrolysis step of AA analysis, resulting in an overestimate of lysine content. Moreover, the presence of Maillard compounds in a food results in inaccurate digestibility coefficients being generated using traditional AA digestibility assays. Recently, a new assay methodology for accurately determining ileal digestible reactive lysine (available lysine) has been developed (Moughan and Rutherfurd, 1996; Rutherfurd et al., 1997). The aim of the present study was to investigate the application of this new assay to a range of high-quality dairy proteinbased products and compare results from the new assay with those found with the traditional true ileal AA digestibility assay.

\section{Comparison of Total Lysine and Reactive Lysine Contents for 12 High-Quality Protein Sources}

There was a high degree of variation among protein sources for agreement between the total lysine and reactive lysine contents. For some protein sources (the infant formulas A and C, elderly formula, and highprotein supplement), there was close agreement. In contrast, for sources such as whole milk powder, evaporated milk, and lactose-hydrolyzed milk powder, total lysine overestimated reactive lysine by $\geq 10 \%$, suggesting the presence of labile lysine derivatives (Maillard products).

It is possible that during the guanidination reaction there is incomplete conversion of lysine to homoarginine, and that the determined reactive lysine values underestimate lysine content. This is unlikely, however, given that conversion of lysine to homoarginine in lysozyme (for which the lysine content is known), which was included in the present study as a quality 
Table 6. Mean $(\mathrm{n}=5)$ true ileal AA digestibility $( \pm \mathrm{SE})$ for 12 dairy protein sources. ${ }^{1,2}$

\begin{tabular}{|c|c|c|c|c|c|c|c|c|c|c|c|c|}
\hline & \multicolumn{2}{|c|}{$\begin{array}{l}\text { Whole } \\
\text { milk powder }\end{array}$} & \multicolumn{2}{|c|}{$\begin{array}{c}\text { Infant } \\
\text { formula A }\end{array}$} & \multicolumn{2}{|c|}{$\begin{array}{c}\text { Infant } \\
\text { formula B }\end{array}$} & \multicolumn{2}{|c|}{$\begin{array}{l}\text { Infant } \\
\text { formula C }\end{array}$} & \multicolumn{2}{|c|}{$\begin{array}{l}\text { Whey protein } \\
\text { concentrate }\end{array}$} & \multicolumn{2}{|c|}{ UHT Milk } \\
\hline & Total & Reactive & Total & Reactive & Total & Reactive & Total & Reactive & Total & Reactive & Total & Reactive \\
\hline $\begin{array}{l}\text { Aspartic } \\
\text { acid }\end{array}$ & $96.9(1.05)^{*}$ & $93.0(1.94)$ & $81.3(3.02)^{*}$ & $70.8(5.89)$ & $85.3(1.66)^{*}$ & $69.5(4.66)$ & $81.9(2.05)$ & $74.6(4.08)$ & $95.0(1.03)$ & $92.7(1.87)$ & $98.2(0.46)^{*}$ & $93.2(1.92)$ \\
\hline Threonine & $97.9(1.30)^{*}$ & $96.4(1.71)$ & $83.1(2.95)^{*}$ & $75.5(4.99)$ & $86.6(1.36)^{*}$ & $84.1(1.99)$ & $83.6(1.65)^{* *}$ & $79.4(1.62)$ & $92.4(1.45)$ & $92.5(2.09)$ & $98.7(0.65)$ & $97.4(1.04)$ \\
\hline Serine & $89.9(1.82)^{* * *}$ & $94.2(2.22)$ & $81.3(3.96)$ & $79.0(4.87)$ & $81.6(2.14)$ & $83.6(1.49)$ & $75.7(3.25)^{*}$ & $80.1(1.92)$ & $92.8(1.58)$ & $94.5(2.01)$ & $92.7(0.73)^{*}$ & $95.7(1.39)$ \\
\hline $\begin{array}{l}\text { Glutamic } \\
\text { acid }\end{array}$ & $94.1(0.86)$ & $94.2(1.02)$ & $86.7(2.27)$ & $86.7(2.93)$ & $87.9(1.03)^{* * *}$ & $91.7(0.65)$ & $85.6(1.56)^{*}$ & $88.5(1.13)$ & $95.6(0.86)$ & $95.4(0.92)$ & $95.5(0.39)$ & $95.7(0.52)$ \\
\hline Glycine & $76.3(6.83)$ & $76.0(7.03)$ & $42.8(17.26)^{*}$ & 54.4 (13.99) & $56.0(3.95)$ & $56.5(4.12)$ & $32.7(12.25)^{*}$ & 43.9 (11.69) & $86.2(3.59)$ & $86.4(3.90)$ & $84.3(3.78)$ & $81.7(4.78)$ \\
\hline Alanine & $100.6(0.88) * * *$ & $98.0(1.09)$ & $72.1(3.07)$ & $73.4(4.21)$ & $79.6(3.30)$ & $80.0(2.68)$ & $76.8(4.07)$ & $80.3(2.43)$ & $97.2(0.93)$ & $96.8(0.94)$ & $101.1(0.39)^{* *}$ & $99.9(0.52)$ \\
\hline Valine & $95.8(0.83)$ & $96.3(0.99)$ & $85.9(2.36)$ & $85.9(2.96)$ & $87.6(1.23)$ & $89.1(1.04)$ & $85.6(1.53)^{*}$ & $88.5(0.92)$ & $96.0(0.96)$ & $96.2(1.02)$ & $97.1(0.38)$ & $97.3(0.48)$ \\
\hline Isoleucine & $93.5(0.97)$ & $93.7(1.28)$ & $84.1(2.73)$ & $83.0(3.71)$ & $87.4(1.15)$ & $88.6(0.94)$ & $82.5(2.01)^{*}$ & $85.6(1.31)$ & $97.1(0.64)$ & $97.2(0.72)$ & $95.6(0.44)$ & $95.6(0.50)$ \\
\hline Leucine & $99.3(0.43)$ & $99.5(0.48)$ & $91.7(1.25)$ & $91.7(1.61)$ & $92.5(0.92)$ & $93.6(0.80)$ & $92.1(0.95)^{*}$ & $93.6(0.62)$ & $98.4(0.49)$ & $98.5(0.52)$ & $99.9(0.17)$ & $99.9(0.25)$ \\
\hline Tyrosine & $101.4(0.32)$ & $101.2(0.44)$ & $92.9(0.96)$ & $92.5(1.44)$ & $91.8(1.37)$ & $92.6(1.44)$ & $93.2(1.00)$ & $94.0(0.69)$ & $100.2(0.83)$ & $100.1(0.78)$ & $101.6(0.11)$ & $101.5(0.22)$ \\
\hline Phenylalanine & $100.8(0.35)^{*}$ & $101.1(0.40)$ & $91.8(1.03)$ & 92.1 & $91.2(1.32)^{*}$ & $92.6(1.29)$ & $93.1(1.10)^{*}$ & $94.3(0.80)$ & $98.5(0.80)$ & $98.7(0.83)$ & $101.2(0.12)$ & $101.3(0.20)$ \\
\hline \multirow[t]{3}{*}{ Histidine } & $99.1(0.78)^{* * *}$ & $89.7(1.14)$ & $88.6(1.85)$ & $84.2(4.43)$ & $88.6(1.42)$ & $87.2(1.80)$ & $90.2(0.91)$ & $86.7(2.60)$ & $95.1(1.50)^{*}$ & $87.0(2.29)$ & $100.3(0.19)^{* *}$ & $92.9(1.38)$ \\
\hline & \multicolumn{2}{|c|}{$\begin{array}{l}\text { Evaporated } \\
\text { milk }\end{array}$} & \multicolumn{2}{|c|}{$\begin{array}{l}\text { Weight gain } \\
\text { formula }\end{array}$} & \multicolumn{2}{|c|}{$\begin{array}{l}\text { Sports } \\
\text { formula }\end{array}$} & \multicolumn{2}{|c|}{$\begin{array}{l}\text { Elderly } \\
\text { formula }\end{array}$} & \multicolumn{2}{|c|}{$\begin{array}{l}\text { Lactose-hydrolyzed } \\
\text { milk powder }\end{array}$} & \multicolumn{2}{|c|}{$\begin{array}{l}\text { High-protein } \\
\text { supplement }\end{array}$} \\
\hline & Total & Reactive & Total & Reactive & Total & Reactive & Total & Reactive & Total & Reactive & Total & Reactive \\
\hline $\begin{array}{l}\text { Aspartic } \\
\text { acid }\end{array}$ & $91.0(2.48)$ & $91.2(1.98)$ & $92.9(1.15)^{*}$ & $88.8(1.70)$ & $90.4(1.09)$ & $91.4(1.12)$ & $88.3(1.18)$ & $83.0(1.13)$ & $96.4(1.00)^{*}$ & $92.2(1.81)$ & $94.9(2.75)$ & $92.4(2.38)$ \\
\hline Threonine & $95.9(1.96)$ & $95.6(1.65)$ & $94.8(1.22)$ & $93.4(1.45)$ & $91.6(1.35)$ & $91.7(1.08)$ & $88.3(1.63)^{* * * *}$ & $85.8(1.46)$ & $97.8(1.09)$ & $96.6(1.89)$ & $96.5(3.32)^{*}$ & $94.6(2.56)$ \\
\hline Serine & $88.5(2.74)^{*}$ & $93.3(1.85)$ & $87.6(1.79)^{*}$ & $89.6(2.07)$ & $82.1(2.38)^{* * *}$ & $86.6(2.86)$ & $86.3(1.79)$ & $86.8(1.37)$ & $88.9(1.83)^{* * * *}$ & $94.9(1.75)$ & $91.6(4.24)$ & $92.7(3.86)$ \\
\hline $\begin{array}{l}\text { Glutamic } \\
\text { acid }\end{array}$ & $92.6(1.36)^{* *}$ & $93.2(1.26)$ & $92.3(0.79)$ & $92.6(0.84)$ & $89.4(1.09)$ & $91.2(0.87)$ & $91.5(0.94)$ & $91.1(0.85)$ & $93.7(0.76)$ & $94.0(1.47)$ & $93.8(2.17)$ & $93.6(2.13)$ \\
\hline Glycine & 76.4 (6.99) & $77.4(6.36)$ & $82.2(3.96)$ & $82.1(3.96)$ & $65.3(7.47)$ & $65.0(7.03)$ & $63.8(7.61)$ & $64.0(7.30)$ & $87.4(3.70)$ & $86.3(2.70)$ & 70.0 (11.65) & $72.4(10.80)$ \\
\hline Alanine & $97.6(1.85)^{* *}$ & $96.4(1.87)$ & $96.2(1.11)^{* *}$ & $95.3(1.17)$ & $94.7(0.91)^{*}$ & $93.0(0.93)$ & 93.7 (1.09) & $92.4(0.76)$ & $100.2(0.77)^{* *}$ & $97.1(3.28)$ & $98.7(2.34)^{* *}$ & $96.6(2.55)$ \\
\hline Valine & $94.6(1.42)^{*}$ & $95.4(1.29)$ & $93.3(0.88)$ & $93.9(0.95)$ & $91.1(1.01)$ & $91.9(1.24)$ & $93.0(0.93)$ & $92.9(0.75)$ & $95.6(0.78)^{* *}$ & $96.0(0.93)$ & $94.9(2.19)$ & $95.1(2.13)$ \\
\hline Isoleucine & $92.3(1.68)^{* * *}$ & $93.2(1.46)$ & $91.5(0.95)$ & $92.1(1.06)$ & $88.9(1.19)$ & $89.7(1.59)$ & $91.9(1.22)$ & $91.8(0.99)$ & $93.1(1.00)$ & $93.3(1.05)$ & $93.8(2.48)$ & $93.7(2.50)$ \\
\hline Leucine & $98.3(0.80)^{*}$ & $98.7(0.74)$ & $97.3(0.51)^{*}$ & $97.7(0.55)$ & $96.5(0.51)$ & $96.6(0.64)$ & $96.7(0.51)$ & $96.8(0.41)$ & $99.3(0.36)^{*}$ & $99.6(1.63)$ & $98.2(1.19)$ & $98.4(1.18)$ \\
\hline Tyrosine & $100.2(0.70)$ & $100.2(0.66)$ & $99.1(0.46)$ & $98.9(0.66)$ & $98.6(0.38)$ & $98.4(0.43)$ & $98.2(0.31)$ & $98.2(0.40)$ & $101.3(0.26)$ & $101.1(0.50)$ & $100.1(0.84)$ & $99.5(1.18)$ \\
\hline Phenylalanine & $99.9(0.70)^{* *}$ & $100.2(0.68)$ & $98.0(0.50)^{*}$ & $98.3(0.58)$ & $97.5(0.38)$ & $97.6(0.49)$ & $98.1(0.35)^{*}$ & $98.3(0.39)$ & $100.7(0.29)^{*}$ & $100.9(0.31)$ & $98.8(1.06)$ & $99.0(1.12)$ \\
\hline Histidine & $95.2(1.75)^{*}$ & $91.2(1.73)$ & $96.7(0.82)^{*}$ & $90.4(1.41)$ & $96.0(1.36)^{* * * *}$ & $87.2(1.40)$ & $94.6(0.69)^{* * * *}$ & $86.5(0.88)$ & $98.9(0.74) * *$ & $90.4(2.73)$ & $97.6(1.89)^{* * * *}$ & $91.2(2.54)$ \\
\hline
\end{tabular}

${ }^{1}$ Values were corrected for endogenous AA flow using the enzymatically hydrolyzed casein method (Moughan et al., 1990; Butts et al., 1991).

${ }^{2}$ Superscripts denote statistically significant differences $(* P<0.05, * * P<0.01, * * * P<0.001)$ between the mean total and reactive lysine digestibilities. 
control, was in excess of $98 \%$. At high $\mathrm{pH}$, the formation of lysinoalanine may also compete with the guanidination reaction for reactive lysine. However, based on studies investigating the formation of lysinoalanine in casein at high $\mathrm{pH}$ (Karayiannis et al., 1979), only a maximum of about $2.5 \%$ of the reactive lysine will convert to lysinoalanine after a 6 -h incubation under the guanidination conditions used here. Furthermore, given that as much as $95 \%$ of guanidination is complete in a soluble protein in the first $8 \mathrm{~h}$ of incubation (Rutherfurd and Moughan, unpublished data), the actual amounts of lysinoalanine formed during guanidination are likely to be much lower than $2.5 \%$ and only a negligible error.

It is apparent that some purified high-protein products, marketed on the basis of high-protein quality, have structural lysine damage during manufacture and storage, and for these products, the traditional total lysine determination overestimates available lysine.

\section{Comparison of True lleal Reactive Lysine Digestibility and Conventional Total Lysine Digestibility}

For all protein sources, true ileal total lysine digestibility was significantly $(P<0.05)$ lower than true ileal reactive lysine digestibility. However, for many of the protein sources tested, including whole milk protein, whey protein concentrate, UHT milk, weight gain formula, elderly formula, sports formula, high-protein supplement, and lactose-hydrolyzed milk powder, the numerical difference between true ileal total and reactive digestibility was small $(<3 \%)$ and of little practical relevance. This suggests the presence of minimal amounts of acid-labile lysine derivatives, and for these particular samples, both the conventional true ileal AA digestibility assay and the new true ileal reactive lysine digestibility assay were suitable methods for determining lysine digestibility. For the infant formulas and evaporated milk, however, the difference between true ileal total and reactive lysine digestibility was $>3 \%$ and as high as $7 \%$. For these protein sources, the new assay provides more meaningful estimates of lysine availability.

It has been appreciated for some time that the conventional true ileal lysine digestibility assay overestimates lysine availability in processed feedstuffs (Batterham et al., 1990). In the present study, the digestible total lysine content was statistically significantly different from the digestible reactive lysine content for all protein sources except the high-protein supplement. Ultimately, and in relation to nutrition, it is the digestible lysine content that is of importance. For several of the protein sources (infant formula B, UHT milk, weight gain formula, and elderly formula), the actual difference between the digestible total lysine and available lysine (digestible reactive lysine) contents was small $(<3 \%)$. For whole milk protein, whey protein concentrate, evaporated milk, sports formula, and lactose-hydrolyzed milk powder; the overestimation of available lysine by digestible lysine ranged from $3.2 \%$ (whey protein concentrate) to $14 \%$ (evaporated milk).

It would appear that even for purified dairy-based protein sources, such as those tested in this study, the traditional true ileal total lysine assay does not always accurately predict available lysine content. The true ileal reactive lysine digestibility assay described here measures the uptake from the small intestine of structurally unaltered lysine molecules and provides more accurate estimates of available lysine.

\section{The True lleal Digestibility of Acid-Stable AA in Protein Sources Determined Following Traditional AA Analysis or After Guanidination of the Protein}

Although the newly developed digestible reactive lysine assay can be used to determine available lysine with accuracy (Rutherfurd et al., 1997), it would be useful if the other acid-stable AA could also be determined with the same procedure. To this end, a statistical comparison was conducted of the mean true ileal AA digestibility determined using either conventional AA analysis or AA analysis following guanidination. Arginine was not examined, as it coeluted with a very large ammonia peak. For most (61\%) of the acid-stable AA, there were no significant differences $(P>0.05)$ between methods, and for a further $19 \%$ of the AA studied, the difference between means, although significant statistically, was $<3 \%$ and arguably not meaningful in practical terms. For the remaining $20 \%$ of AA tested, the new method did not predict ileal digestibility accurately compared with the conventional method. Histidine was the AA that showed the greatest absolute differences between the 2 methods for most protein products; tyrosine showed the least difference.

It appears that the digestible reactive lysine assay can be used to determine available lysine without affecting the estimation of the majority of the acid-stable AA.

\section{Amino Acid Quality of the Milk-Based Products}

All the milk-based products tested were highly digestible. This is consistent with other milk products that have been tested in our laboratory, such as sodium and calcium caseinate, milk protein isolate, $\alpha$-lactalbumin, lactic casein, and whey protein concentrates 
(Rutherfurd and Moughan, 1998). The most poorly digested AA was glycine, with a true ileal digestibility for the 12 milk products ranging from 33 to $87 \%$ and a mean digestibility of $70 \%$. The most highly digestible AA was tyrosine, with a digestibility ranging from 92 to $102 \%$ and a mean digestibility of $98 \%$. The digestibility of a few of the AA was slightly $>100 \%$, reflecting complete digestion and absorption of these AA. Experimental error explains the overestimate in digestibility. The infant formulas tended to have the lowest AA digestibility, with mean true AA digestibility for the formulas ranging from 81 to $84 \%$ for the acid-stable AA (apart from lysine) tested. The cause of the relatively low digestibility is unknown but should be investigated further

The gross reactive lysine content of the milk products ranged from 9.5 to $78.6 \mathrm{mg} / \mathrm{g}$. This variation is largely due to the inclusion level of milk proteins into the products. The digestibility of reactive lysine was similar to the digestibility values obtained for most of the other AA and ranged from 91 to $100 \%$. As was the case with the acid-stable AA, the digestibility of reactive lysine tended to be lowest in the infant formulas. The UHT milk was the most digestible protein source in terms of reactive lysine.

\section{CONCLUSIONS}

The traditional true ileal AA digestibility assay is inaccurate for measuring available lysine in some processed protein sources. This is particularly true for protein sources that have been heat-processed and that contain reducing sugars. The true ileal digestible reactive lysine assay used in this study to measure available lysine does accurately determine available lysine. Although for a number of the protein sources tested there was little difference between the total lysine digestibility and the reactive lysine digestibility, there were statistically significant and sizable differences in digestible reactive lysine content and digestible total lysine content for some of the milk products. Consequently, it would appear that the conventional ileal total lysine digestibility assay may not be accurate for all processed milk products.

It would appear in general that milk provides a highly digestible protein source for inclusion into other foods.

\section{REFERENCES}

Batterham, E. S., L. M. Andersen, R. D. Baigent, R. E. Darnell, and M. R. Taverner. 1990. A comparison of the availability and ileal digestibility of lysine in cottonseed and soyabean meals for grower/finisher pigs. Br. J. Nutr. 64:663-677.

Butts, C. A., P. J. Moughan, and W. C. Smith. 1991. Endogenous amino acid flow at the terminal ileum of the rat determined under conditions of peptide alimentation. J. Sci. Food Agric. 55:175-187.

Costigan, P., and K. J. Ellis. 1987. Analysis of faecal chromium derived from controlled release marker devices. N.Z. J. Technol. 3:89-92.

Ferrer, E., A. Alegria, R. Farre, P. Abellan, and F. Romero. 2003. Fluorometric determination of chemically available lysine: Adaptation, validation and application to different milk products. Nahrung 47:403-407.

Hurrell, R. F., and K. J. Carpenter. 1981. The estimation of available lysine in foodstuffs after Maillard reactions. Prog. Food Nutr. Sci. 5:159-176.

Karayiannis, N. I., J. T. MacGregor, and L. F. Bjeldanes. 1979. Lysinoalanine formation in alkali-treated proteins and model peptides. Food Cosmet. Toxicol. 17:585-590.

Moughan, P. J. 2003. Amino acid availability: Aspects of chemical analysis and bioavailability methodology. Nutr. Res. Rev. 16:127-141.

Moughan, P. J., A. J. Darragh, W. C. Smith, and C. A. Butts. 1990. Perchloric and trichloroacetic acids as precipitants of protein in endogenous ileal digesta from the rat. J. Sci. Food Agric. 52:13-21.

Moughan, P. J., and S. M. Rutherfurd. 1996. A new method for determining digestible reactive lysine in foods. J. Agric. Food Chem. 44:2202-2209.

National Research Council. 1995. Nutrient requirement of the laboratory rat. In Nutrient Requirements of Laboratory Animals. 4th ed. National Academy of Sciences, Washington, DC.

Pereyra Gonzales, A. S., G. B. Naranjo, L. S. Malec, and M. S. Vigo. 2003. Available lysine, protein digestibility and lactulose in commercial infant formulas. Int. Dairy J. 13:95-99.

Ramirez-Jimenez, A., B. Garcia-Villanova, and E. Guerra-Hernandez. 2004. Effect of storage conditions and inclusion of milk on available lysine in infant cereals. Food Chem. 85:239-244.

Rutherfurd, S. M., and P. J. Moughan. 1998. The digestible amino acid composition of several milk proteins: Application of a new bioassay. J. Dairy Sci. 81:909-917.

Rutherfurd, S. M., P. J. Moughan, and P. C. H. Morel. 1997. Assessment of the true ileal digestibility of reactive lysine as a predictor of lysine uptake from the small intestine of the growing pig. J. Agric. Food Chem. 45:4378-4383.

SAS User's Guide: Statistics. 1999. SAS Inst., Inc., Cary, NC. 